\title{
SIMULTANEOUS DETERMINATION OF SOME STEROID HORMONES IN MILK AND DAIRY PRODUCTS BY LIQUID CHROMATOGRAPHY TANDEM MASS SPECTROMETRY (LC-MS/MS)
}

\author{
Vu Ngoc Tu ${ }^{1^{*}}$, Do Thi Thu Hang ${ }^{1}$, Le Dinh $\mathrm{Chi}^{2}$, Dau Chi Mai ${ }^{2}$, Dang Thi Hien', \\ Tran Cao Son ${ }^{1}$ \\ ${ }^{1}$ National Institute for Food Control \\ ${ }^{2}$ Hanoi University of Pharmacy \\ ${ }^{3}$ University of Science, Vietnam National University - Hanoi
}

(Received on: 22/3/2019; Revised on: 20/5/2019; Accepted on: 27/5/2019)

\begin{abstract}
A sensitive method has been developed and validated for simultaneous determination of some steroid hormones (trenbolone, 17 $\beta$-estradiol, progesterone, testosterone, estrone, melengestrol acetate and zeranol). Samples were hydrolyzed to release analytes, and analytes were then extracted from sample matrix using QuEChERS technique, detected and quantified by using reversed phase liquid chromatography coupled with tandem mass spectrometry. The tandem mass spectrometric detection was done by using ESI ion source working in positive mode and multiple reaction monitoring (MRM) quantitation. Validation results show that the method is sensitive and selective for analyzing seven steroid hormones on milk and dairy products. The quantitation limit of the method for these analytes ranged from 0.1 to $2.0 \mu \mathrm{g} / \mathrm{kg}$. Method recovery was from 70.4 to $110.0 \%$. Relative coefficient of variation varied from 2.7 to $12 \%$. The method was applied to determine steroid hormones in 40 milk and dairy product samples collected from different markets and commercial centers in Hanoi.
\end{abstract}

Keywords: LC-MS/MS, QuEChERS, steroid hormones, milk, dairy

\section{INTRODUCTION}

Milk and dairy products are a popular and important food group in human diet, providing nutritional ingredients to improve the physical development. For the majority of children, milk and dairy products are the main daily diets. However, to increase profits, hormones that stimulate milk production in livestock is increasingly abused, which result in unwanted residues of these hormones in bovine milk and tissues. Up to now, steroid hormones (estradiol, melengestrol acetate, progesterone, testosterone, trenbolone) have been detected in milk. Estradiol and progesterone are natural female hormones; testosterone is a natural male hormone; zeranol, trenbolone acetate, and melengestrol acetate are synthetic growth stimulants. There is clear evidence that certain hormones could cause endocrine disorders and other undesirable effects on humans [1].

Various analytical methods have been used to identify steroid hormones in milk and dairy products such as ELISA, GC-MS or LC-MS/MS. Among these, ELISA is a simple method and requires low investment in equipment. However, it could not simultaneously identify several steroid hormones and may raise false positives. GC-MS method has high sensitivity and accuracy but the sample

\footnotetext{
I*Tel:0984459988Ｅmail: vungoctu1986@gmail.com
} 
preparation procedure is complicated and expensive due to the need of using different type of reagents to derivatize the analytes [2]. Compared to the above methods, the LC-MS/MS method has many outstanding advantages like simple sample preparation procedure, short analysis time, and, most importantly, the capacity of simultaneous analysis a large number of substances with high specificity, sensitivity and accuracy. Many publications have described the LC-MS/MS methods to simultaneously identify steroid hormones in milk and dairy product matrices [3-5]. Barreir et al. determined six natural sex hormones (pregnenolone, progesterone, dehydroepiandrosterone, estrone, testosterone, and androstenedione) in infant formula [3]. Up to now, there has been no official method for simultaneous determination of all seven sex hormones (estradiol, melengestrol acetate, progesterone, testosterone, trenbolone) in milk and dairy products in Vietnam.

This study aims at developing, validating and applying a method for simultaneous determination of seven common steroid hormones in milk and dairy products using LC-MS/MS, providing a technical solution for the control of these compounds in Vietnam.

\section{MATERIALS AND METHODS}

\subsection{Standards and Materials}

Standard substances of trenbolone, 17 $\beta$-estradiol, progesterone, testosterone, estrone, melengestrol acetate, and zeranol were obtained from LGC (Germany).

Samples used for method development, validation and application were powdered milk, liquid milk, yogurt, whey, butter and cheese randomly purchased in various markets and commercial centers in Hanoi.

\subsection{Reagents}

Sodium chloride P.A. grade and acetic acid P.A. grade were purchased from Merck Chemical (Germany). Beta-glucuronidase enzyme $5000 \mathrm{U}$ was purchased from Sigma Aldrich (Singapore) and the absorbents PSA, and $\mathrm{C}_{18}$ were provided by Agilent Technology (USA).

\subsection{Instrumentation}

LC-MS/MS 5000 QQQ system of SCIEX, USA was used in this study. Other equipment used includes shake incubator (Amerex, USA), pH meter (Metter Toledo, Switzerland), analytical balance (Metter Toledo, Switzerland), centrifuge (Hettich, Germany), vortex mixer (IKA, China), ultrasonic bath (Elma, Germany), etc.

\subsection{Method development and validation}

Firstly, the mass spectral conditions were optimized to identify the precursor and product ions. Two transitions were selected for each compound. Then, liquid chromatographic conditions (chromatographic column, mobile phase composition and gradient program) were selected. Finally, sample preparation steps ( $\mathrm{pH}$ condition, enzyme content, hydrolysis temperature, hydrolysis time, extracting salt, dispersion sorbent) were investigated and optimized.

Referred to previous publications [3-5], the hydrolyzed process combined with QuEChERS methodology was selected. The proposed procedure was as follows: about $10 \mathrm{~g}$ of the homogenized sample was accurately weighed into a $50 \mathrm{~mL}$ centrifuge tube. Ten $\mathrm{mL}$ of acetate buffer $(\mathrm{pH}=5.2$ ) was added into the tube, and mixed by vortex within one minute, followed by adding $150 \mu \mathrm{L} \beta$-glucuronidase $5000 \mathrm{U} / 5 \mathrm{~mL}$, and the tube was mixed again within one minute. After the addition of $10 \mathrm{~mL}$ of acetonitrile and the salt mixture $\left(4 \mathrm{~g} \mathrm{MgSO}_{4}\right.$ anhydrous and $\left.1 \mathrm{~g} \mathrm{NaCl}\right)$, the tube was shaken vigorously within one minute and centrifuged within five minutes at $6000 \mathrm{rpm}$. One $\mathrm{mL}$ of the supernatant was pipetted into a $2 \mathrm{~mL}$ centrifuge tube containing adsorption mixture (150 mg $\mathrm{MgSO}_{4}$ and $\left.50 \mathrm{mg} \mathrm{C18}\right)$. The tube was then covered, shaken and centrifuged within three minutes at $13000 \mathrm{rpm}$. The extraction solution was filtered through a 0.2 $\mu \mathrm{m}$ membrane prior to being analyzed by LC-MS/MS.

The method was validated in terms of selectivity, the limit of detection, the limit of 
quantification, linearity, precision (repeatability), trueness (recovery). Validation data were assessed and compared to European regulations (EC/657/2002) and $\mathrm{AOAC}[6,7]$.

\section{RESULTS AND DISCUSSION}

\subsection{LC-MS/MS condition optimization}

\subsubsection{Selection of mass spectral conditions}

Precursor and product ions were determined by using direct injection into the tandem mass spectrometry system, using a sample needle of $1 \mathrm{~mL}$ for directly injecting $1 \mu \mathrm{g} / \mathrm{mL}$ of hormone standard solutions. The product ions which appear with the highest intensity and stability were used for the quantitation and the other ones which have lower intensity were used to confirm the purpose. The optimized MS/MS conditions were shown in Table 1.

Table 1. Analysis conditions of seven steroid hormonesby LC-MS/MS

\begin{tabular}{|c|c|c|c|c|c|}
\hline Analyte & $\begin{array}{c}\text { Precusor ion } \\
\qquad(\mathbf{m} / \mathbf{z})\end{array}$ & $\begin{array}{l}\text { Product ions } \\
\qquad(\mathrm{m} / \mathbf{z})\end{array}$ & $\begin{array}{c}\text { Collision } \\
\text { energy } \\
(\mathrm{eV})\end{array}$ & $\begin{array}{l}\text { Collision cell } \\
\text { exit potential } \\
\text { (volts) }\end{array}$ & Note \\
\hline \multirow{2}{*}{ Trenbolone } & \multirow{2}{*}{271} & 253 & 27 & 16 & Quantified \\
\hline & & 199 & 35 & 24 & Identified \\
\hline \multirow{2}{*}{$17 \beta$-estradiol } & \multirow{2}{*}{255} & 133 & 19 & 16 & Quantified \\
\hline & & 159 & 20 & 18 & Identified \\
\hline \multirow{2}{*}{ Progesterone } & \multirow{2}{*}{315} & 109 & 30 & 18 & Quantified \\
\hline & & 97 & 26 & 22 & Identified \\
\hline \multirow{2}{*}{ Testosterone } & \multirow{2}{*}{289} & 97 & 26 & 18 & Quantified \\
\hline & & 109 & 26 & 18 & Identified \\
\hline \multirow{2}{*}{ Estrone } & \multirow{2}{*}{271} & 159 & 20 & 20 & Quantified \\
\hline & & 157 & 20 & 18 & Identified \\
\hline \multirow{2}{*}{ Melengestrol Acetate } & \multirow{2}{*}{397} & 337 & 20 & 18 & Quantified \\
\hline & & 279 & 20 & 20 & Identified \\
\hline \multirow{2}{*}{ Zeranol } & \multirow{2}{*}{321} & 277 & -30 & -16 & Quantified \\
\hline & & 303 & -30 & -18 & Identified \\
\hline \multirow{2}{*}{ Progesterone $-\mathrm{d} 9$} & 324 & 113 & 30 & 16 & \multirow{2}{*}{$\begin{array}{l}\text { Internal } \\
\text { standard }\end{array}$} \\
\hline & 324 & 100 & 22 & 20 & \\
\hline
\end{tabular}

\subsubsection{Investigation into liquid chromatography conditions}

The analyzed steroid hormones are compounds with low polarity; hence, the $\mathrm{C} 18$ reverse phase chromatographic column is selected due to its suitability. Reverse phase chromatographic column Symmetry C18 $(150 \mathrm{~mm} \times 3.0 \mathrm{~mm}$ id; $3.5 \mu \mathrm{m})$ and corresponding pre-columns from Waters were used to separate the hormones in the study.

The investigation of the mobile phase system with two components: (A) water with the added substrate and (B) acetonitrile or methanol was used for research. Prepare a mixture of seven hormones of $10 \mu \mathrm{g} / \mathrm{L}$ concentration to investigate the composition and the mobile phase gradient. The results of the survey of mobile phase were presented in Table 2. 
Table 2. Investigation of mobile phase conditions

\begin{tabular}{|c|c|c|c|c|}
\hline \multirow[b]{2}{*}{ Mobile phase } & \multicolumn{4}{|c|}{ Signal intensity } \\
\hline & $\begin{array}{c}\text { A: Water } \\
\text { (acetic acid } \\
0.1 \% \text { )\&B: } \\
\text { Acetonitrile }\end{array}$ & $\begin{array}{c}\text { A: Water } \\
\text { (acetic acid } \\
\text { 0.1\%)\& B: } \\
\text { Methanol }\end{array}$ & $\begin{array}{c}\text { A: Water } \\
\text { (formic acid } \\
\text { 0.1\%)\&B: } \\
\text { Acetonitrile }\end{array}$ & $\begin{array}{c}\text { A: Water } \\
\text { (formic acid } \\
\text { 0.1\%)\&B: } \\
\text { Methanol }\end{array}$ \\
\hline Trenbolone & 29,700 & 9,800 & 50,367 & 3,600 \\
\hline $17 \beta$-estradiol & 19,800 & 3,700 & 23,200 & No peak \\
\hline Progesterone & 28,400 & 8,500 & 51,400 & 2,100 \\
\hline Testosterone & 81,300 & 7,600 & 27,200 & 1,800 \\
\hline Estrone & 11,500 & 5,500 & 26,300 & 1,500 \\
\hline Melengestrol acetate & 15,900 & 6,300 & 25,800 & 1,700 \\
\hline Zeranol & 14,500 & 4,300 & 43,000 & No peak \\
\hline
\end{tabular}

The optimized mobile phase gradient condition was specified as followed: initial 30\% B (five minutes); increase to $90 \%$ from five to nine minutes, maintain within 1 minute; decrease to $30 \%$. Total analyzed time was 15 minutes.

\subsection{Investigation into the sample preparation}

The selected sample was a children's supplement drink which was detected with four substances (trenbolone, progesterone, testosterone, estrone). The sample was spiked with the standard solution of three undetectable substances in the sample (17 $\beta$-estradiol, melengestrol acetate, zeranol). Then, the whole sample was shaken and stored for 24 hours at the temperature of $2 \div 8^{\circ} \mathrm{C}$ before processing.

\subsubsection{Selection of pH of buffer solution}

Carry out the tests with different $\mathrm{pH}$ values $(4.6,5.0$ and 5.2) of the buffer solution. The result was given in Figure 1.

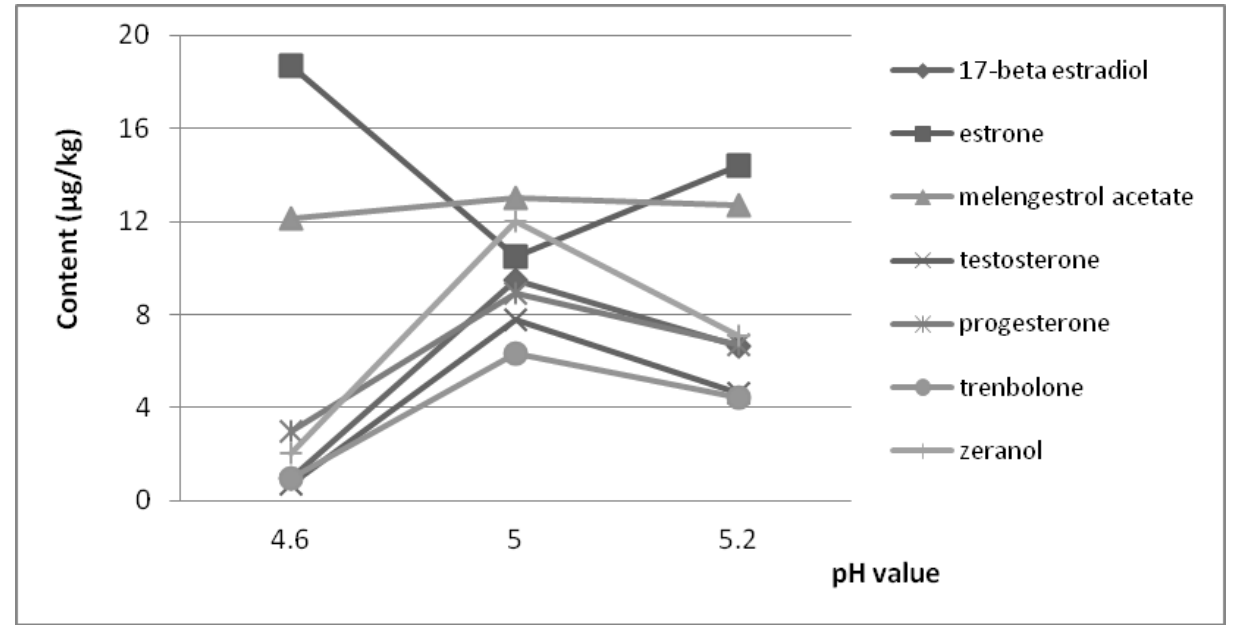

Figure 1. Comparison the pH of buffer solution

The results in Figure 1 showed that the obtained results at three $\mathrm{pH}$ values were different. The contents of six hormones (except estrone) at $\mathrm{pH}=4.6$ were lower than those of other $\mathrm{pH}$ values. 
The obtained content of substances at $\mathrm{pH}=5.2$ was lower than that at $\mathrm{pH}=5.0$ (with exception of melengestrol acetate, whose content was a bit higher at $\mathrm{pH}=5.2$ ). Moreover, better stability of analysis results were observed at $\mathrm{pH}=5.0$. Therefore, $\mathrm{pH}=5.0$ is the optimal value of the acetate buffer in this study.

\subsubsection{Evaluation of enzyme amount}

Preliminary trials were done with 4 different amounts of enzyme: no. $25,50,100,150 \mu \mathrm{L} \beta$ glucuronidase 5,000 U solution/5 mL water. Results of these expriments were presented in Figure 2.

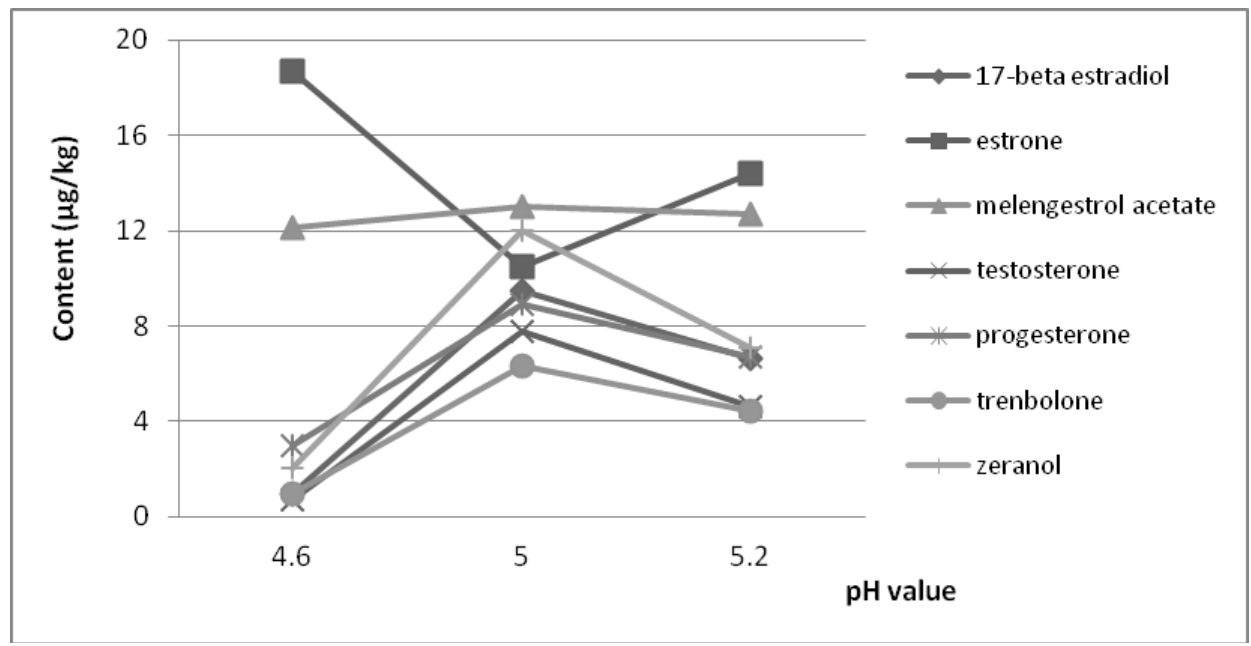

Figure 2. Evaluation of enzyme amount

The results in Figure 2 pointed out that the recovery of the substances changed while changing the added amount of enzyme. The lowest efficiency was observed at $25 \mu \mathrm{L}$ of enzyme solution then it increased rapidly when using $50,100 \mu \mathrm{L}$ of enzyme solution and changed not significantly when increased to $150 \mu \mathrm{L} \beta$-glucuronidase solution $5,000 \mathrm{U} / 5 \mathrm{~mL}$ of water. These results demonstrated that the most suitable amount of enzyme was $100 \mu \mathrm{L}$. This amount was sufficient for complete ydrolysis of the sample. In order to both ensure the efficiency of the method and to save costs, 100 $\mu \mathrm{L} \beta$-glucuronidase solution of $5,000 \mathrm{U} / 5 \mathrm{~mL}$ was selected as the optimal amount of enzyme.

\subsubsection{Selection of components of the salt mixture in the extraction}

Preliminary trials were done on three types of salt mixture: four $\mathrm{g} \mathrm{MgSO}_{4}$ and one $\mathrm{g} \mathrm{NaCl}$ (mixture 1); four $\mathrm{g} \mathrm{MgSO}_{4}$ and one $\mathrm{g} \mathrm{CH}_{3} \mathrm{COONa}$ (mixture 2); four $\mathrm{g} \mathrm{MgSO}_{4}$, one $\mathrm{g} \mathrm{NaCl}$, one $\mathrm{g}$ sodium citrate and $0.5 \mathrm{~g}$ sodium citrate tribasic dehydrate (mixture 3 ).

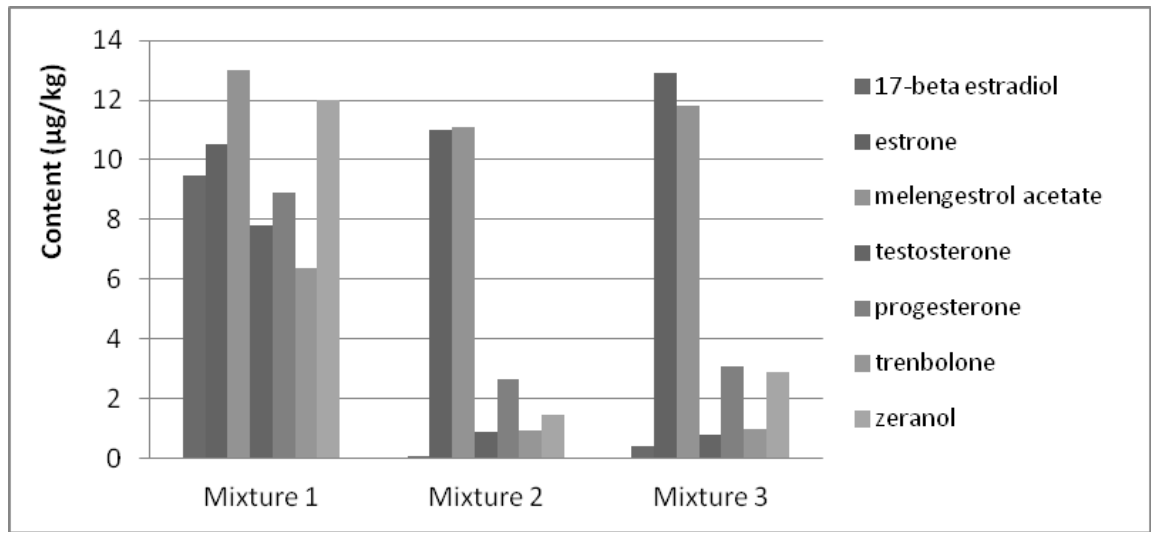

Figure 3. Diagram for investigation of salt mixture in the extraction

The results in Figure 3 pointed out that there were no major difference in estrone and melengestrol contents when changing the salt mixtures. Perhaps these two hormones were not 
significantly affected by the choice of salt mixtures. Meanwhile, the content of other five hormones are greatly affected by the presence of acetate and citrate salts. When acetate and citrate salts were present in the salt mixture, the concentration of these five hormones decreased drastically. It was probable that these two salts had changed the $\mathrm{pH}$ of the sample solution, rendered it not suitable for the extraction of these steroid hormones. So the salt mixture $1\left(4 \mathrm{~g} \mathrm{MgSO}_{4}\right.$ anhydrous, $1 \mathrm{~g} \mathrm{NaCl}$ ) is the most suitable one for the extraction process.

\subsection{Method validation}

\subsubsection{Selectivity}

The blank, standard and spiked samples with concentration of each hormone at $10 \mu \mathrm{g} / \mathrm{kg}$ in milk and butter matrices were analyzed using the optimized method. An example of chromatograms of testosterone are presented in Figure 4.

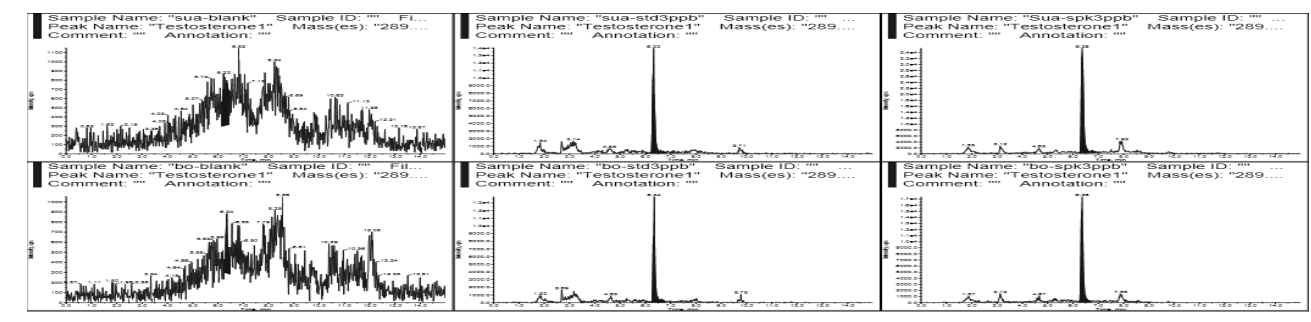

Figure 4. Chromatograms of blank, standard and spiked sample (testosterone)

The given chromatograms in Figure 4 revealed that there was no signal within the retention time window of the analyte. Retention time of compound in standard and spiked sample have the deviation that did not exceed 5\%, which conformed to Europe regulation (EC/657/2002).

Number of identification points (IPs) and ion ratio of seven hormones were gathered in Table 3.

Table 3. Number of IPs and ion ratioof seven steroid hormones

\begin{tabular}{|l|c|c|c|c|c|c|}
\hline \multicolumn{1}{|c|}{ Analyte } & $\begin{array}{c}\text { Precusor } \\
\text { ion }\end{array}$ & $\begin{array}{c}\text { Produc } \\
\text { Ions }\end{array}$ & IPs & $\begin{array}{c}\text { Standard sample } \\
\text { ion ratio }\end{array}$ & $\begin{array}{c}\text { Spiked sample } \\
\text { ion ratio }\end{array}$ & $\begin{array}{c}\% \\
\text { deviation }\end{array}$ \\
\hline Trenbolone & 271 & $253 / 199$ & 4 & 34.7 & 31.5 & $\pm 20 \%$ \\
\hline $17 \beta$-estradiol & 255 & $133 / 159$ & 4 & 63.8 & 54.1 & $\pm 25 \%$ \\
\hline Progesterone & 315 & $109 / 97$ & 4 & 40.9 & 43.1 & $\pm 20 \%$ \\
\hline Testosterone & 289 & $97 / 109$ & 4 & 29.5 & 33.8 & $\pm 20 \%$ \\
\hline Estrone & 271 & $159 / 157$ & 4 & 43.6 & 47.0 & $\pm 20 \%$ \\
\hline $\begin{array}{l}\text { Melengestrol } \\
\text { acetate }\end{array}$ & 397 & $337 / 279$ & 4 & 58.4 & 51.6 & $\pm 25 \%$ \\
\hline Zeranol & 321 & $277 / 303$ & 4 & 31.8 & 28.5 & $\pm 20 \%$ \\
\hline
\end{tabular}

The results in Table 3 confirmed that number of IP points and the ion ratio of seven hormones all met the Europe regulations for analysis using tandem mass spectrometry (EC/657/2002).

\subsubsection{Limit of detection (LOD) and limit of quantification (LOQ)}

The spiked samples at the concentration of $0.1 \mu \mathrm{g} / \mathrm{kg}$ for trenbolone, progesterone; at $1 \mu \mathrm{g} / \mathrm{kg}$ for $17 \beta$-estradiol, testosterone, estrone and melengestrol acetate), and at $2 \mu \mathrm{g} / \mathrm{kg}$ for zeranol were analyzed and the ratio of $\mathrm{S} / \mathrm{N}$ for each analyte was calculated. The results of LOD and LOQ were summarized in Table 4. 
Table 4. $L O D$ and $L O Q$ value of seven steroid hormones

\begin{tabular}{|l|c|c|c|c|c|c|c|}
\hline $\begin{array}{c}\text { Hormone } \\
(\boldsymbol{\mu g} / \mathbf{k g})\end{array}$ & Trenbolone & $\begin{array}{c}\mathbf{1 7 \beta}- \\
\text { estradiol }\end{array}$ & Progesterone & Testosterone & Estrone & $\begin{array}{c}\text { Melengestrol } \\
\text { acetate }\end{array}$ & Zeranol \\
\hline LOD & 0.1 & 1.0 & 0.1 & 1.0 & 1.0 & 1.0 & 2.0 \\
\hline LOQ & 0.3 & 3.0 & 0.3 & 3.0 & 3.0 & 3.0 & 6.0 \\
\hline
\end{tabular}

In comparison to previous studies, the obtained LOD and LOQ value of this study was significantly better. LODs varied from 0.3 to $6.0 \mu \mathrm{g} / \mathrm{kg}$, guaranteed the method sensitivity for the intended application.

\subsubsection{Linearity}

Linearity of steroid hormones was determined by analyzing different standard solutions with the concentration from 0,3 to $30 \mathrm{mg} / \mathrm{L}$ (trenbolone, progesterone), from 3 to $300 \mathrm{mg} / \mathrm{L}$ ( $17 \beta$-estradiol, testosterone, estrone, melengestrol acetate; from 6,0 to $300 \mathrm{mg} / \mathrm{L}$ (zeranol) in blank matrices. All the calibration curves have the coefficients of determination $\left(\mathrm{R}^{2}\right)$ higher than 0.995 which meet the criteria.

\subsubsection{Repeatability and recovery}

The repeatability and recovery of the method are validated by analyzing the spiked samples at three different concentrations with six replicates at each concentration. Results were shown in Table 5.

Table 5. Results of repeatabilityand recovery

\begin{tabular}{|c|l|c|c|}
\hline No. & \multicolumn{1}{|c|}{ Hormone } & R (\%) & RSD (\%) \\
\hline 1 & Trenbolone & $83.7 \div 106.0$ & $5.4 \div 11.0$ \\
\hline 2 & $17 \beta$-estradiol & $77.3 \div 105.0$ & $5.7 \div 8.4$ \\
\hline 3 & Progesterone & $76.0 \div 93.3$ & $4.0 \div 9.2$ \\
\hline 4 & Testosterone & $83.3 \div 102.0$ & $5.8 \div 7.0$ \\
\hline 5 & Estrone & $76.3 \div 110.0$ & $4.6 \div 7.0$ \\
\hline 6 & Melengestrol acetate & $97.3 \div 110.0$ & $2.7 \div 5.0$ \\
\hline 7 & Zeranol & $70.4 \div 101.0$ & $3.5 \div 12.0$ \\
\hline
\end{tabular}

The obtained results showed that the method have the recovery in the range of $70.4 \div 110 \%$, and the relative deviation in the range of $2,7 \div 12,0 \%$ which conformed with the AOAC International's regulation.

\subsection{Application for analyzing steroid hormone in milk and dairy products}

The method was applied for the determination of seven steroid hormones in 40 milk and dairy products collected from different markets in Hanoi. The results are listed in Table 6.

Table 6. Testing of hormone in milk and dairy product samples

\begin{tabular}{|c|c|c|c|c|c|c|}
\hline \multirow{2}{*}{ Analyte } & \multicolumn{2}{|c|}{ Milk Powdered } & \multicolumn{2}{c|}{ Liquid Milk } & \multicolumn{2}{c|}{ Other Dairy Products } \\
\cline { 2 - 7 } & $\begin{array}{c}\text { Number of } \\
\text { detected } \\
\text { sample }\end{array}$ & $\begin{array}{c}\text { Content } \\
(\boldsymbol{\mu g} / \mathbf{k g})\end{array}$ & $\begin{array}{c}\text { Number of } \\
\text { detected } \\
\text { sample }\end{array}$ & $\begin{array}{c}\text { Content } \\
(\boldsymbol{\mu g} / \mathbf{k g})\end{array}$ & $\begin{array}{c}\text { Number of } \\
\text { detected } \\
\text { sample }\end{array}$ & $\begin{array}{c}\text { Content } \\
(\boldsymbol{\mu g} / \mathbf{k g})\end{array}$ \\
\hline Trenbolone & $0 / 10$ & $-*$ & $1 / 10$ & $<0.3$ & $8 / 20$ & $0.44 \div 34$ \\
\hline $17 \beta$-estradiol & $0 / 10$ & - & $0 / 10$ & - & $0 / 20$ & - \\
\hline
\end{tabular}

14 | Vietnamese Journal of Food Control (No. 2-2019) 


\begin{tabular}{|c|c|c|c|c|c|c|}
\hline Progesterone & $8 / 10$ & $3.5 \div 12$ & $8 / 10$ & $1.9 \div 13$ & $11 / 20$ & $0.63 \div 34$ \\
\hline Testosterone & $0 / 10$ & - & $1 / 10$ & $<3.0$ & $0 / 20$ & - \\
\hline Estrone & $5 / 10$ & $11 \div 22$ & $8 / 10$ & $3.5 \div 26$ & $2 / 20$ & $3.1 \div 3.6$ \\
\hline $\begin{array}{c}\text { Melengestrol } \\
\text { acetate }\end{array}$ & $0 / 10$ & - & $0 / 10$ & - & $0 / 20$ & - \\
\hline
\end{tabular}

*Not detected

Analysis on 40 samples detected the presence of estrone in five powdered milk samples, eight liquid milk samples and two dairy products; that of progesterone in eight powdered milk samples, eight liquid milk samples and eleven dairy products. Especially, trenbolone was detected in one liquid milk sample and eight dairy products; testosterone was detected in one liquid milk sample which requires a more stringent control on steroid hormones content in milk and dairy products.

\section{CONCLUSION}

Method for simultaneous determination of seven steroid hormones (estrone, $17 \beta$ - estradiol, progesterone, testosterone, trenbolone, melengestrol acetate, zeranol) was developed and validated, completely satisfied the regulation of AOAC International and Europe. The method could be applied to determine steroid horme in milk powderd, liquid milk or dairy products.

\section{Acknowlegdement}

We would like to thank the National Institute for Food Control for funding this study.

\section{REFERENCES}

1. Vietnam Ministry of Health (2009), Vietnam national pharmacopoeia, Medical Publishing House, Hanoi.

2. I. Matraszek-Zuchowska, B. Wozniak, A. Posyniak (2017) "Determination of Hormone Resi dues in Milk by Gas Chromatography-Mass Spectrometry”, Food Analytical Methods, 10(3), 727-739.

3. R. Barreiro, P. Regal, M. Díaz-Bao, C. A. Fente and A. Cepeda (2015), “Analysis of Naturally Occurring Steroid Hormones in InfantFormulas by HPLC-MS/MS and Contribution to Dietary Intake", Foods, 4, 605-621.

4. X. Qu, C. Su, N. Zheng, S. Li, L. Meng, and J. Wang (2017), “A Survey of Naturally-Occurring Steroid Hormonesin Raw Milk and the Associated Health Risks inTangshan City, Hebei Province, China", International Journal of Environmental Research and Public Health, 15(38), 1-11.

5. F. Courant, J.P. Antignac, D. Maume, F. Monteau, F. Andre (2007), "Determination of naturally occurring estrogens and androgens in retail samples of milk and eggs", Food Additives and Contaminants, 24(12), 1358-1366.

6. AOAC International (2012), “Appendix F: Guidelines for Standard Method Performance Re quirements", Official Method of Analysis of AOAC International, $19^{\text {th }}$ edition, AOAC, USA.

7. European Commision (2002), "2002/657/EC: Commission Decision of 12 August 2002 im plementing Council Directive 96/23/EC concerning the performance of analytical methods and the interpretation of results" 


\section{Tóm tắt \\ XÁC ĐỊNH ĐỒNG THOÒI MỘT SỐ HORMON STEROID TRONG SŨ๋A VÀ CÁC SẢN PHẨM TỬ SỮA BẢNG KỸ THUẠTT LC-MS/MS \\ Vũ Ngọc Tú ${ }^{1}$, Đỗ Thị Thu Hằng ${ }^{1}$, Lê Đình $\mathrm{Chi}^{2}$, Đậu Chi Mai², Đặng Thị Hiên ${ }^{3}$, Trần Cao Sơn ${ }^{1}$ \\ ${ }^{1}$ Viện Kiểm nghiệm an toàn vệ sinh thực phẩm quốc gia \\ ${ }^{2}$ Truờng Đại học Dược Hà Nội \\ ${ }^{3}$ Truờng Đại học Khoa học tư nhiên, Đại học Quốc gia Hà Nội}

Phương pháp xác định đồng thời một số hormon steroid (gồm trenbolone, $17 \beta$-estradiol, progesterone, testosterone, estrone, melengestrol acetate và zeranol) đã được xây dựng dựa trên quy trình xử lý mẫu thủy phân kết hợp với chiết QuEChERS và phân tích bằng kỹ thuật LC-MS/MS. Hệ thống sắc ký lỏng với cột $\mathrm{C} 18$ pha đảo, detector khối phổ ba tứ cực nguồn ESI $(+)$ và chế độ theo dõi ion MRM đã được sử dụng trong nghiên cứu. Kết quả thẩm định cho thấy phương pháp có độ nhạy và chọn lọc cao đối với 7 hormon trên nền mẫu sữa và các sản phẩm sữa. Phương pháp cho phép xác định các hormon ở mức hàm lượng thấp với giới hạn định lượng trong khoảng $0,1 \div 2,0 \mu \mathrm{g} / \mathrm{kg}$. Quy trình có độ thu hồi trong khoảng $70,4 \div$ $110,0 \%$, độ lệch chuẩn tương đối trong khoảng $2,7 \div 12,0 \%$. Phương pháp đã được ứng dụng để xác định hàm lượng 7 hormon steroid trong 40 mẫu sữa, sản phẩm sữa được thu thập trên thị trường Hà Nội.

Tù khóa: LC-MS/MS, QuEChERS, hormon steroid, sũa 